\title{
Selection for milk constituents in dairy cattle
}

\author{
JARMO JUGA \\ Finnish Animal Breeding Association \\ P.O. Box 40, 01301 Vantaa, Finland
}

\begin{abstract}
Alternative selection combinations of milk traits were studied by the selection index method. The current pricing system in Finland does not encourage weighting fat or protein content, while the most profitable objective, when looking at farmer's net income, is breeding for milk yield. Because of low protein content in milk and consumer attitudes, which prefer protein to fat, the main objective in the Finnish dairy cattle breeding program is protein yield. Selection for protein yield changes the protein to fat ratio to desirable direction by increasing the protein content and decreasing the fat content. Changes in constituents are small though. Changing the breeding objective from protein yield to protein content would require a considerable change in the pricing system.
\end{abstract}

Index words: breeding goal, milk, protein, protein- $\%$, selection index

\section{Introduction}

The breeding program in Finnish dairy cattle has produced a moderate improvement in milk yield and milk fat content. The breed averages of milk recorded cows were in 1988

\begin{tabular}{lcccccccc}
\hline & milk & FCM & & \multicolumn{2}{c}{ fat } & & \multicolumn{2}{c}{ protein } \\
& $\mathrm{kg}$ & $\mathrm{kg}$ & & $\mathrm{kg}$ & $\%$ & & $\mathrm{~kg}$ & $\%$ \\
\hline Ayrshire & 5915 & 6266 & & 260 & 4.40 & & 190 & 3.21 \\
Friesian & 6009 & 6109 & & 247 & 4.12 & & 190 & 3.15 \\
Finn cattle & 5067 & 5417 & & 226 & 4.46 & & 167 & 3.30 \\
\hline
\end{tabular}

The fat surplus and the interest of dairy industry to increase the protein content were the main reasons for setting up a project to determine new breeding goals for milk production and to develop better indices to reach the goal.

Gibson (1987) showed that an increase in fat to protein ratio of raw milk would best meet most western markets. The situation in Finland is quite opposite however, with the fat to protein ratio being 1.35 rather than 1.1 typical to production figures in many western countries. This high fat to protein ratio simultaneously with milk surpluses has led to overproduction of butter fat and resulted in de- 
Table 1. Net economic weights of milk components in Finland in 1989.

The price per $\mathrm{kg}$ of milk

with $4.3 \%$ of fat and $3.2 \%$ of protein

The price per $0.1 \%$ of fat

2.69 Fmk

The price per $0.1 \%$ of protein

$.015 \mathrm{Fmk}$

$.032 \mathrm{Fmk}$

Hence the price per $\mathrm{kg}$ of carrier is

$2.69-43 \times .015-32 \times .032=1.02 \mathrm{Fmk}$

The price per $\mathrm{kg}$ of fat

$15.0+1.021=16.02 \mathrm{Fmk}$

The price per $\mathrm{kg}$ of protein $32.0+1.021=33.02 \mathrm{Fmk}$

cross price - energy costs $=$ net return

\begin{tabular}{lrlrl} 
Carrier & 1.02 & -18 & $=.84 \mathrm{Fmk}$ \\
Fat & 16.02 & - & 8.28 & $=7.74 \mathrm{Fmk}$ \\
Protein & 33.02 & - & 5.22 & $=27.80 \mathrm{Fmk}$ \\
\hline
\end{tabular}

mand for reducing the ratio. Selecting against fat content and for protein content is difficult because of the high positive genetic relationship between the traits, but not impossible as shown by Kennedy (1982).

Gibson (1987) also pointed out that provided returns per $\mathrm{kg}$ of fat and protein are positive, an index giving equal weighting per $\mathrm{kg}$ fat and protein is likely to be very close to optimal. The net economic weights for carrier, fat and protein (table 1) are equal to partial derivatives of total profit function of milk production with respect to carrier, fat and protein (Wilmink, 1988), but they can simply be calculated as a substraction of feed costs from the prices of carrier, fat and protein. The price of fat and protein includes also the price of carrier. Although the net returns of fat and protein in Finland are positive, a considerable price is paid for carrier which makes it profitable for a farmer to select mainly for milk yield.
Dommerholt and Wilmink (1986) and Wilmink (1988) showed that from the farmers' perspective selection on economic indices is of interest although some other selection criteria might be of national interest. Selection against the national interest might result in reduced prices, however. The best way of reducing the conflict between national and farmers' interests is to set the prices of milk components to support national interests.

\section{Material and methods}

Genetic and phenotypic parameters for milk production traits used in the selection index computations were estimates from Finnish ayrshire population (Torniainen, 1990). The data comprised of 305-day 1st lactation records of all cows born in 1981-1983. Only daughters of young bulls with at least 50 daughters were included. Variance components were estimated using half-sib analysis. The statistical model was mixed model with year-season, age at calving, gestation length and type of feeding as fixed effects, the herd average in milk production as a covariate and sires as random effects (for more details, TORNIAINEN, 1990). The parameters obtained are given in Table 2 .

The effect of alternative economic weights on the genetic change of the milk traits was studied by using selection index methodology (e.g. FAlCONER, 1981). The breeding goal $(\mathbf{H})$ is defined as a function of additive genetic values and economic weights (a). Usually $\mathbf{H}$ is not observable and hence an index (I) is used as a selection criterion. Index is a function of

Table 2. Genetic and phenotypic parameters of milk traits (Torniainen, 1990).

\begin{tabular}{lcccrrrr}
\hline & $\sigma_{\mathrm{p}}$ & $\mathrm{h}^{2}$ & $\begin{array}{c}\text { Milk } \\
\text { yield }\end{array}$ & $\begin{array}{c}\text { Fat } \\
(\%)\end{array}$ & $\begin{array}{c}\text { Prot. } \\
(\%)\end{array}$ & $\begin{array}{r}\text { Fat } \\
\text { yield }\end{array}$ & $\begin{array}{r}\text { Prot. } \\
\text { yield }\end{array}$ \\
\hline Milk yield & 887 & .26 & 1.00 & -.27 & -.28 & 0.75 & .89 \\
Fat (\%) & .46 & .43 & -.51 & 1.00 & .45 & .42 & -.07 \\
Prot. (\%) & .21 & .51 & -.59 & .68 & 1.00 & .04 & .17 \\
Fat yield & 40 & .21 & .55 & .44 & .05 & .05 & .79 \\
Prot. yield & 28 & .18 & .77 & -.10 & .00 & 1.00 \\
\hline
\end{tabular}

Above diagonal phenotypic correlations. Below diagonal genetic correlations. 
observations (x) and weighting factors (b). Given the economic weights the index coefficients can be calculated from

$$
\mathbf{P b}=\mathbf{G a}
$$

where $\mathbf{P}$ is the covariance matrix between the observations and $\mathbf{G}$ is the covariance matrix between the observations and additive genetic values. The genetic progress in any trait in $\mathbf{H}$ is calculated by the regression of additive genetic values on $\mathbf{I}$. The number of traits in $\mathbf{H}$ and $\mathbf{I}$ does not necessarily have to be the same. The genetic progress in traits in $\mathbf{H}$ results either from direct selection on the trait itself or from correlated response due to selection on other traits.

In the study the selection index is used to select bulls for milk traits. Bulls are assumed to have 150 daughters and a selection intensity of 1.0 is used. The obtained genetic responce is hence only a result of bull selection, while cow selection is negleted.

\section{Results and discussion}

Current selection objective in milk traits is protein yield which is the only milk trait included in the overall bull index. Also cow index is based solely on protein yield. The expected correlated response from selecting for protein yield in protein and fat content is shown in the first alternative (I) in Table 3. Assuming the genetic parameters are correct the selection for protein yield changes the fat to protein ratio, slowly though, to right direction if the national interest is concerned.

If selection was solely on milk yield (alternative II), that is the case in many countries, the response in milk yield would be approximately $100 \mathrm{~kg}$ more per generation than when selection is for protein yield (I). Both the fat and protein content would be decreasing rapidly. In fact if decreasing the fat content was the only concern, selection for milk yield would be an effective mean to do so.

Maximum change in milk constituents is naturally achieved by a direct selection on pro- tein and fat content. If all the selection pressure is put to increase the protein content (III) the response in milk yield would be highly negative, but both fat and protein content would be increasing. Because of the large variation in fat the correlated response in fat would be even greater than the direct response in protein. Selection against fat content (IV) would result in maximum decrease in fat, but also protein would go down and positive response in milk yield would be achieved. Actually selection against fat content would result in nearly the same response in milk characteristics as selection for milk yield.

The simultaneous selection to decrease fat content and increase protein content is possible by setting equal but opposite weights to fat and protein (V). The outcome is decreased milk and fat but increased protein yield. If the weight for protein is doubled, the increase in protein content is greater, but also the change in fat content turns positive. The change in constituents is somewhat smaller if protein yield is included in selection (VI), but it gives a moderate increase in milk yield.

An intensified selection for protein which includes simultaneous selection for protein content and protein yield results in decreased milk production if equal weights are used (VII). By doubling the weight for protein yield (VIII) the response in milk production is turned positive. In both the alternatives the change in fat content is also positive and bigger than that of protein content.

One general remark can be drawn from Table 3 . If one wishes to decrease the fat content and increase the protein content the change in fat content is always bigger and hence the dry matter of milk is decreased. This leads evidently to higher transport and drying expenses.

When looking from farmers' perspective one should maximize the genetic change in milk components which maximizes the net return of milk production. When current prices paid for milk, fat and protein are used ( $\mathrm{I}$ in table 4), the optimum would be to select for 
Table 3. Genetic change per generation in milk traits with alternative selection criterias (selection intensity $=1$, b = weight)

\begin{tabular}{|c|c|c|c|c|c|c|c|}
\hline & \multirow{2}{*}{$\begin{array}{l}\text { Selected } \\
\text { trait }\end{array}$} & \multirow{2}{*}{ (b) } & \multicolumn{5}{|c|}{ Genetic change } \\
\hline & & & $\begin{array}{l}\text { milk } \\
\text { yield }\end{array}$ & $\begin{array}{l}\text { fat } \\
(\%)\end{array}$ & $\begin{array}{c}\text { prot. } \\
(\%)\end{array}$ & $\begin{array}{c}\text { fat } \\
\text { yield }\end{array}$ & $\begin{array}{l}\text { prot. } \\
\text { yield }\end{array}$ \\
\hline I) & prot.kg & $(1)$ & 326 & -.03 & .01 & 12.4 & 11.1 \\
\hline II) & milk kg & $(1)$ & 432 & -.15 & -.08 & 9.6 & 8.7 \\
\hline III) & prot.- $\%$ & $(1)$ & -261 & .20 & .15 & .9 & .6 \\
\hline IV) & fat- $\%$ & $(-1)$ & 224 & -.29 & -.10 & -7.5 & 1.2 \\
\hline V) & $\begin{array}{l}\text { fat- } \% \\
\text { prot.- } \%\end{array}$ & $(-1)$ & -71 & -.09 & .07 & -8.0 & 2.1 \\
\hline VI) & $\begin{array}{l}\text { prot.- } \% \\
\text { prot.kg }\end{array}$ & $\begin{array}{l}(+1) \\
(+1)\end{array}$ & -64 & .16 & .13 & 6.7 & 5.9 \\
\hline VII) & $\begin{array}{l}\text { prot.- } \% \\
\text { prot.kg }\end{array}$ & $\begin{array}{l}(+1) \\
(+2)\end{array}$ & 70 & .11 & .10 & 9.6 & 8.5 \\
\hline VIII) & $\begin{array}{l}\text { fat- } \% \\
\text { prot.- } \% \\
\text { prot.kg }\end{array}$ & $\begin{array}{l}(-1) \\
(+1) \\
(+2)\end{array}$ & 210 & -.07 & .04 & 5.2 & 9.5 \\
\hline
\end{tabular}

yield traits and neglect fat and protein content. This will mostly result in increased milk yield with less dry matter. One would think that from the dairy industry and national perspective the opposite should be optimal. However, it seems to be difficult to change the pricing system to encourage farmers to select for dry matter and especially for protein content.

The dominating effect of milk yield is clearly seen in alternative II (table 4) where all the price paid for dry matter is set for protein and fat has a negative economic weight. Still the most selection pressure goes to milk yield.

If the goal is to decrease the fat to protein ratio, i.e. decrease the fat content and increase the protein content, the price should be solely on protein. As a result both milk yield and fat have negative economic weights because of energy required to produce lactose and fat. When all the price is set for protein (III in table 4), the change in fat and protein content is almost twice the change in alternative $\mathrm{I}$ and yield traits will still be improving quite moderately.

A new pricing system has been effective from January 1990 in Finland, in which the price of 0.1 protein- $\%$ has been increased to
0.05 Fmk and the price of 0.1 fat $-\%$ has been decreased to $0.013 \mathrm{Fmk}$. The price per 0.1 fat- $\%$ for milk where fat- $\%$ is above 3.7 is only 0.008 Fmk. Because practically all the Finnish cows have higher than $3.7 \%$ fat content, the effect of pricing system is that no extra price is paid for higher fat. The price covers the energy costs of fat production, however. Hence the economical weight for fat production is set to zero. $80 \%$ of the base

Table 4. Economic weights (a), index weights (b) and genetic responses (dG) per generation (selection intensity $=1$ ) in milk traits.

\begin{tabular}{rrrrrrr}
\hline & & $\begin{array}{c}\text { Milk } \\
\text { yield }\end{array}$ & $\begin{array}{c}\text { Fat } \\
(\%)\end{array}$ & $\begin{array}{c}\text { Prot. } \\
(\%)\end{array}$ & $\begin{array}{c}\text { Fat } \\
\text { yield }\end{array}$ & $\begin{array}{r}\text { Prot. } \\
\text { yield }\end{array}$ \\
\hline I) & a: & .84 & & & 7.74 & 27.8 \\
& b: & .90 & & & 1.60 & 33.1 \\
& dG: & 398 & -.07 & -.04 & 13.1 & 10.4 \\
II) & a: & .84 & & & -8.28 & 47.8 \\
& b: & 1.10 & & & -22.20 & 59.0 \\
& dG: & 397 & -.12 & -.04 & 9.9 & 10.4 \\
III) & a: & -.18 & & & -8.28 & 78.8 \\
& b: & .08 & & & -23.30 & 91.1 \\
& dG: & 300 & -0.5 & .02 & 10.6 & 11.0 \\
IV) & a: & .37 & & & 0 & 45.3 \\
& b: & .51 & & & -9.3 & 53.0 \\
& dG: & 370 & -.06 & -.02 & 12.1 & 11.0 \\
\hline
\end{tabular}


price is contributed by dry matter of which protein is dominating. Although more weight is given to dry matter, the pricing encourages the farmer to produce carrier rather than dry matter (IV). This is mainly because net returns from increased milk production are superior to returns from increased protein and the increase in fat production is negleted.

Estimation of economic weights for milk components might not be as straightforward as shown here. Firstly, the price of milk varys within the country due to subsidies and taxes. Secondly, inclusion of all costs and rescaling to fixed output has been shown to be important (GiBson, 1989). Although different methods produce widely different absolute and relative economic weights (GIBSON, 1989) the weights used here should give an idea of importance of different milk components to milk production.

\section{Conclusion}

The current pricing system does not encourage farmers to select for milk protein content but for milk yield. Current overproduction in milk fat and low protein content in milk has made it necessary to increase the protein content and to decrease the fat content. Changing the criteria for selection results in conflict between breeding goal and pricing, which is unbearable in the long run. Hence the pricing of milk should be changed to better reflect the breeding goal.

\section{References}

FALCONER, D.S. 1981. Introduction to Quantitative Genetics (2nd edn.). Longman, London. p. 340.

Dommerholt, J. \& Wilmink, J.B.M. 1986. Optimal selection responses under varying milk prices and margins for milk production. Livest. Prod. Sci. 14: 109-121.

Gıson, J.P. 1987. The options and prospects for genetically altering milk composition in dairy cattle. Anim. Breed. Abstr. 55: 231-243.

Gipson, J.P. 1989. Selection on the major components of milk: Alternative methods of deriving economic weights. J. Dairy Sci. 72: 3176-3189.

\section{SELOSTUS}

\section{Maidon kuiva-ainekomponenttien jalostus lypsykarjan jalostusohjelmassa}

\section{Jarmo Juga}

\section{Suomen Kotieläinjalostusyhdistys}

Pl. 40, 01301 Vantaa

Erilaisten valintaohjelmien vaikutusta maitoominaisuuksien perinnölliseen edistymiseen tarkasteltiin valintaindeksimenetelmällă. Pyrittäessä jalostusvalinnalla parantamaan maidontuotannon kannattavuutta tilatasolla
Kennedy, B.W. 1982. Reducing fat in milk and dairy products by breeding. J. Dairy Sci. 65: 443-449.

Torniainen, P. 1990. Maidon aineosien periytymisasteet ja geneettiset yhteydet. MSc.-Thesis, University of Helsinki, Dept. of Animal Breeding.

WILMINK, J.B.M. 1988. Selection on fat and protein to maximise profit in dairy herds. Livest. Prod. Sci. 20: $299-316$.

Ms received december 18, 1989 suosii maidon nykyinen hinnoittelu nestemäärän lisäămistä maidon kuiva-ainekomponenttien kustannuksella. Kulutustottumuksissa tapahtuvan voimakkaan muutoksen ja maidon laskevan valkuaispitoisuuden seurauksena on 
jalostustavoitteeksi Suomessa maito-ominaisuuksien osalta hyväksytty valkuaistuotos. Valinta valkuaismäärän suhteen lisaaả määrällisiă maito-ominaisuuksia sekă muuttaa valkuais-rasva-suhdetta toivottuun suuntaan pienentämällă rasvapitoisuutta ja parantamalla valkuaispitoisuutta. Pitoisuuksien osalta muutos on tosin suhteellisen hidas- ta. Jos jalostusvalinnassa haluttaisiin lisătă painoa valkuaispitoisuudelle edellyttäisi se huomattavaa muutosta maidon tilitysperusteissa, sillă jalostustavoitteiden tulee olla sopusoinnussa tuotannon kannalta taloudellisesti merkittävien ominaisuuksien kanssa. 